\title{
Acetylcholine-regulated $\mathrm{K}^{+}$current remodelling in the atrium after myocardial infarction and valsartan administration
}

\author{
Qing-yan Zhao MD PhD, Cong-xin Huang MD PhD, Hong Jiang MD PhD, Emmy Okello MBchB, \\ Xi Wang MD, Yan-hong Tang MD, Geng-shan Li MD
}

Q-y Zhao, C-x Huang, H Jiang, et al. Acetylcholine-regulated $\mathrm{K}^{+}$ current remodelling in the atrium after myocardial infarction and valsartan administration. Can J Cardiol 2009;25(4):e115-e118.

BACKGROUND: Atrial fibrillation (AF) is a common complication of myocardial infarction (MI). Angiotensin II receptor antagonists prevent the promotion and propagation of AF. However, the activation of the acetylcholine-regulated $\mathrm{K}^{+}$current $\left(\mathrm{I}_{\mathrm{K}, \mathrm{ACh}}\right)$ in the atrium after $\mathrm{MI}$ and the effect of valsartan on $\mathrm{I}_{\mathrm{K}, \mathrm{ACh}}$ are less understood.

METHODS: Twenty-four adult rabbits were randomly divided into three groups: sham-operated, MI and MI plus valsartan administration (MI+valsartan). The sham-operated group received a median sternotomy without left ventricular coronary artery ligation. Both the MI group and the MI+valsartan group received a median sternotomy followed by ligation of the midpoint of the left ventricular coronary artery. The MI+valsartan group was administered oral valsartan for 12 weeks. After 12 weeks, the initiation of $\mathrm{AF}$ was measured by vagal stimulation followed by quick excision of the heart. $\mathrm{I}_{\mathrm{K}, \mathrm{ACh}}$ in the left atrial myocardium was measured by the patch clamp technique.

RESULTS: AF was induced in four animals in the MI group, two in the sham-operated and two in the MI+valsartan groups, with the total AF duration expectedly longer in the MI group than in the sham-operated and $\mathrm{MI}+$ valsartan groups ( $38 \mathrm{~s}$ versus $9 \mathrm{~s}$ and $9 \mathrm{~s}$, respectively). Furthermore, the mean $\left( \pm\right.$ SEM) density of $\mathrm{I}_{\mathrm{K}, \mathrm{ACh}}$ increased significantly more in the left atrial myocardia of the MI group than in the sham-operated and the MI+valsartan groups $(-13 \pm 0.42 \mathrm{pA} / \mathrm{pF}$ versus $-9 \pm 0.38 \mathrm{pA} / \mathrm{pF}$ and $-10 \pm 0.37 \mathrm{pA} / \mathrm{pF}$, respectively at $-100 \mathrm{mV}$; and $4.1 \pm 0.28 \mathrm{pA} / \mathrm{pF}$ versus $3.1 \pm 0.27 \mathrm{pA} / \mathrm{pF}$ and $3.3 \pm 0.27 \mathrm{pA} / \mathrm{pF}$, respectively at $20 \mathrm{mV} ; \mathrm{P}<0.05)$. However, there was no statistically significant difference in $\mathrm{I}_{\mathrm{K}, \mathrm{ACh}}$ between the sham-operated group and the MI+valsartan group.

CONCLUSIONS: AF is associated with increased $I_{K, A C h}$ after MI. Inhibition of increased $\mathrm{I}_{\mathrm{K}, \mathrm{ACh}}$ may be the mechanism by which valsartan prevents AF following MI.

Key Words: Atrial fibrillation; Myocardial infarction; Rabbit; Valsartan
Le remodelage du courant $\mathrm{K}+$ induit par

l'acétylcholine dans l'oreillette après un infarctus du myocarde et l'administration de valsartan

HISTORIQUE : La fibrillation auriculaire (FA) est une complication courante de l'infarctus du myocarde (IM). Les antagonistes des récepteurs de l'angiotensine II préviennent la promotion et la propagation de la FA. Cependant, on comprend moins l'activation du courant $\mathrm{K}+$ induit par l'acétylcholine $\left(\mathrm{I}_{\mathrm{k} . \mathrm{ACh}}\right)$ dans l'oreillette après l'IM et l'effet du vasaltran sur $\mathrm{l}_{\mathrm{k}, \mathrm{ACh}}$.

MÉTHODOLOGIE : Vingt-quatre lapins adultes ont été divisés aléatoirement en trois groupes : opération placebo, IM et IM associé à l'administration de valsartan (IM+valsartan). Le groupe ayant subi une opération placebo a reçu une sternotomie médiane sans ligature de l'artère coronaire ventriculaire gauche. Tant le groupe d'IM que le groupe d'IM+valsartan ont subi une sternotomie médiane suivie d'une ligature au milieu de l'artère coronaire ventriculaire gauche. Le groupe d'IM+valsartan a reçu du valsartan par voie orale pendant 12 semaines. Au bout de 12 semaines, l'apparition de FA était mesurée par stimulation vagale suivie d'une excision rapide du cœur. On a mesuré l'I $\mathrm{k}_{\text {.ACh }} \mathrm{du}$ myocarde auriculaire gauche au moyen de la technique du patch-clamp.

RÉSULTATS : La FA a été induite chez quatre animaux du groupe d'IM, deux de ceux ayant subi une opération placebo et deux du groupe d'IM+valsartan, et comme prévu, la durée totale de la FA était plus longue dans le groupe d'IM que dans le groupe ayant subi une opération placebo ou l'IM+valsartan (38 s par rapport à $9 \mathrm{~s}$ et $9 \mathrm{~s}$, respectivement). De plus, la densité moyenne $( \pm \mathrm{ET}) \mathrm{d}_{\mathrm{k} . \mathrm{ACh}}$ a beaucoup plus augmenté dans le myocarde auriculaire gauche du groupe d'IM que du groupe ayant subi l'opération placebo ou l'IM+valsartan $(-13 \pm 0,42 \mathrm{pA} / \mathrm{pF}$ par rapport à $-9 \pm 0,38 \mathrm{pA} / \mathrm{pF}$ et $-10 \pm 0,37 \mathrm{pA} / \mathrm{pF}$, respectivement, à $-100 \mathrm{mV}$; et $4,1 \pm 0,28 \mathrm{pA} / \mathrm{pF}$ par rapport à $3,1 \pm 0,27 \mathrm{pA} / \mathrm{pF}$ et $3,3 \pm 0,27 \mathrm{pA} / \mathrm{pF}$, respectivement, à $20 \mathrm{mV} ; \mathrm{P}<0,05)$. Cependant, il n'y avait pas de différence statistiquement significative d'I $\mathrm{k}_{\mathrm{k} . \mathrm{ACh}}$ entre le groupe ayant subi une opération placebo et le groupe d'IM+valsartan.

CONCLUSIONS : La FA s'associe à une augmentation de l' $I_{k . A C h}$ après l'IM. L'inhibition de l'I $I_{\text {k.ACh }}$ accrue peut être le mécanisme par lequel le valsartan peu prévenir la FA après l'IM.

suppressing electrical and structural cardiac remodelling (9). Modulation of $\mathrm{K}^{+}$currents by angiotensin II has also been reported (10). In the present study, we investigated the changes in $\mathrm{I}_{\mathrm{K}, \mathrm{ACh}}$ and compared the respective current densities in the left atrium of normal and MI rabbits. Furthermore, we observed the effect of valsartan on $\mathrm{I}_{\mathrm{K}, \mathrm{ACh}}$.

\section{METHODS}

The protocol of the present study was approved by the Research and Ethics Committee of Wuhan University (Wuhan, Hubei, People's Rupublic of China). Animal handling was performed according to the Wuhan Directive for Animal Research. antagonists also prevent the promotion and propagation of AF by

Department of Cardiology, Renmin Hospital of Wuhan University, Wuhan, Hubei, People's Republic of China

Correspondence: Dr Cong-xin Huang, Department of Cardiology, Renmin Hospital of Wuhan University, 238 JieFang Road, Wuhan, Hubei 430060,

People's Republic of China. Telephone 86-27-61299325, fax 86-27-88040334, e-mail ruyan1971@yahoo.com.cn

Received for publication June 24, 2007. Accepted October 19, 2007 


\section{Preparation of the animal model}

Twenty-four adult New Zealand white rabbits (weight $1.5 \mathrm{~kg}$ to $2.0 \mathrm{~kg}$ ) were randomly divided into three groups: the sham-operated group $(n=8)$, the MI group ( $\mathrm{n}=8)$ and the MI plus valsartan administration (MI+valsartan) group $(n=8)$.

The rabbits were anesthetized in the abdomen with intravenous sodium pentobarbital (30 mg/kg to $40 \mathrm{mg} / \mathrm{kg}$ ); additional doses were administered when required throughout the experiment. The animals were intubated and ventilated with room air supplemented with lowflow oxygen from a mechanical ventilator. Surgery was performed under sterile conditions. A thoracotomy was performed through the third intercostal space and the heart was exposed after excising the pericardium. The sham-operated group received a median sternotomy without ligation of the left ventricular coronary artery. Both the MI and MI+valsartan groups received a median sternotomy followed by ligation of the midpoint of the left ventricular coronary artery. MI was confirmed by regional cyanosis and electrocardiographic change (more than two ST segment elevations of $0.1 \mathrm{mV}$ or higher). After this, the $\mathrm{MI}+$ valsartan group was administered $10 \mathrm{mg} / \mathrm{kg} /$ day of oral valsartan (Beijing Nuohua Medicine Co Ltd, China) for 12 weeks.

\section{Experimental protocol}

After 12 weeks, the rabbits were anesthetized once more and the double cervical vagosympathetic trunks were severed. An electrocardiogram of leads II and aVF was continuously used to monitor the animals. Silver wires were introduced in the double cranial end of the vagosympathetic trunks toward the heart. Electrical stimulation was delivered at a frequency of $10 \mathrm{~Hz}$, with a $0.2 \mathrm{~ms}$ pulse duration and a voltage of $5 \mathrm{~V}$ (electrophysiology stimulator SEN-7103; Nihon Kohden, Japan). The voltage chosen for the vagal stimulation (VS) was $5 \mathrm{~V}$ higher than the voltage at which a sinus arrest lasting longer than $2 \mathrm{~s}$ (complete atrioventricular block) was achieved. The initiation of AF was measured. When AF was induced, electrical stimulation was terminated. If the duration of electrical stimulation lasted for $30 \mathrm{~s}$ and $\mathrm{AF}$ was not induced, electrical stimulation was also terminated.

\section{Patch-clamp techniques}

After VS, the hearts were extracted and perfused on a Langendorff apparatus at $37^{\circ} \mathrm{C}$ by pumping with calcium-free Tyrode's solution. Following a 3 min perfusion with calcium-free Tyrode's solution, the low calcium $(100 \mu \mathrm{mol} / \mathrm{L})$ Tyrode's solution containing $0.40 \mathrm{mg} / \mathrm{mL}$ type I collagenase was perfused for approximately $8 \mathrm{~min}$. The heart was then detached from the cannula. The left atria were sliced into small pieces and placed in a beaker containing $1.5 \mathrm{~mL}$ of recirculated enzyme solution and $10 \mathrm{~mL}$ of calcium-free Tyrode's solution with $1 \%$ bovine serum albumin. The left atrial pieces were agitated and incubated in the same solution at $37^{\circ} \mathrm{C}$. After $5 \mathrm{~min}$, the cell suspension was filtered through nylon gauze $(200 \mu \mathrm{m}$ mesh) and the calcium concentration was gradually increased to $2 \mathrm{mmol} / \mathrm{L}$ within $30 \mathrm{~min}$. Finally, the cells were stored at room temperature for at least $1 \mathrm{~h}$ before use.

The isolated cells were perfused with Tyrode's solution containing $136 \mathrm{mM}$ sodium chloride, $5.4 \mathrm{mM}$ potassium chloride, $1 \mathrm{mM}$ calcium chloride, $1 \mathrm{mM}$ magnesium chloride, $10 \mathrm{mM}$ glucose and $10 \mathrm{mM}$ HEPES ( $\mathrm{pH}$ 7.4). Ionic currents were recorded with whole-cell clamp methods, using an EPC-9 amplifier (HEKA Instruments Inc, USA). The pipette solution contained $110 \mathrm{mM}$ potassium aspartate, $20 \mathrm{mM}$ potassium chloride, $1 \mathrm{mM}$ magnesium chloride, $5 \mathrm{mM}$ magnesium ATP, $0.1 \mathrm{mM}$ GTP, $10 \mathrm{mM}$ EGTA, $5 \mathrm{mM}$ phosphocreatine and $10 \mathrm{mM}$ HEPES ( $\mathrm{pH}$ adjusted to 7.3 with potassium hydroxide). To record $\mathrm{I}_{\mathrm{K}, \mathrm{ACh}}$, other subtypes of muscarinic ACh receptors were inhibited by using the following subtype-selective antagonists: $100 \mathrm{nM}$ pirenzepine (an M1 blocker), 2 nM 4-diphenylacetoxy-N-methylpiperidine methobromide (an M3 inhibitor) and $200 \mathrm{nM}$ tropicamide (an M4 inhibitor). $\mathrm{I}_{\mathrm{K}, \mathrm{ACh}}$ was induced by $1 \mu \mathrm{M}$ ACh and recordings of $\mathrm{I}_{\mathrm{K}, \mathrm{ACh}}$ were generally conducted with $1 \mu \mathrm{M}$ dofetilide and $20 \mu \mathrm{M}$ chromanol $293 \mathrm{~B}$ in the bathing solution to block the rapidly and slowly activating components of the delayed rectifier $\mathrm{K}^{+}$current. Contamination from the sodium current was prevented by holding the cell at $-50 \mathrm{mV}$. Cadmium chloride $(200 \mu \mathrm{M})$ was used to inhibit the $\mathrm{Ca}^{2+}$ current as well as the $\mathrm{Ca}^{2+}$-activated chloride current. ATP-sensitive $\mathrm{K}^{+}$current, if any, was suppressed by $10 \mu \mathrm{M}$ glyburide in the perfusate and $5 \mathrm{mM}$ magnesium ATP in the pipette (11). $\mathrm{I}_{\mathrm{K}, \mathrm{ACh}}$ was induced by $1 \mu \mathrm{M}$ ACh in the bathing solution and defined as the $1 \mu \mathrm{M}$ atropine-sensitive current to exclude contamination from the background inward rectifier $\mathrm{K}^{+}$current.

\section{Statistical analysis}

Data were analyzed using SPSS 11.0 (SPSS Inc, USA). Values are expressed as mean \pm SEM. Statistical comparisons were made using ANOVA. Paired and unpaired comparisons were conducted using Student's $t$ test. Statistical significance was assumed for $\mathrm{P}<0.05$.

\section{Initiation of $\mathrm{AF}$}

\section{RESULTS}

In the sham-operated group, AF was induced in two rabbits. AF duration was $3 \mathrm{~s}$ in one rabbit and $6 \mathrm{~s}$ in the other. In the MI group, AF was induced in four rabbits. AF duration was $7 \mathrm{~s}, 9 \mathrm{~s}, 10 \mathrm{~s}$ and $12 \mathrm{~s}$ in the four rabbits, respectively. In the MI+valsartan group, AF was induced in two rabbits. AF duration was $4 \mathrm{~s}$ in one rabbit and $5 \mathrm{~s}$ in the other.

\section{Correlation of $\mathrm{I}_{\mathrm{K}, \mathrm{ACh}}$ density in the three groups}

$\mathrm{I}_{\mathrm{K}, \mathrm{ACh}}$ was induced by $1 \mu \mathrm{M}$ ACh in the bathing solution and defined as the $1 \mu \mathrm{M}$ atropine-sensitive current to exclude contamination from the background inward rectifier $\mathrm{K}^{+}$current. $\mathrm{I}_{\mathrm{K}, \mathrm{ACh}}$ demonstrated strong inward rectification with increasing inward currents during hyperpolarizing voltage steps and rapidly decaying outward currents during depolarization. The amplitude of $\mathrm{I}_{\mathrm{K}, \mathrm{ACh}}$ was measured at the end of the $2 \mathrm{~s}$ voltage steps. $\mathrm{I}_{\mathrm{K}, \mathrm{ACh}}$ determined at $2 \mathrm{~s}$ had stronger inward rectification with smaller outward currents on membrane depolarization. As illustrated, the density of $\mathrm{I}_{\mathrm{K}, \mathrm{ACh}}$ was substantially lower in the left atrial myocytes from the sham-operated and MI+valsartan groups than in those from the MI group $(-9 \pm 0.38 \mathrm{pA} / \mathrm{pF}$ and $-10 \pm 0.37 \mathrm{pA} / \mathrm{pF}$ versus $-13 \pm 0.42 \mathrm{pA} / \mathrm{pF}$, respectively at $-100 \mathrm{mV}$; and $3.1 \pm 0.27 \mathrm{pA} / \mathrm{pF}$ and $3.3 \pm 0.27 \mathrm{pA} / \mathrm{pF}$ versus $4.1 \pm 0.28 \mathrm{pA} / \mathrm{pF}$, respectively at $20 \mathrm{mV} ; \mathrm{P}<0.05)$. In the sham-operated and $\mathrm{MI}+$ valsartan groups, $\mathrm{I}_{\mathrm{K}, \mathrm{ACh}}$ showed an increasing trend, but this did not reach statistical significance (Figure 1).

\section{DISCUSSION}

AF can occur secondary to postinfarction complications. However, when it occurs independently, it carries a worse prognosis $(2,12)$. There is considerable interest in the role of the renin-angiotensinaldosterone system in the development of AF (13). Recent reports have suggested that there is a reduction in the development or recurrence of $\mathrm{AF}$ in patients treated with angiotensin-converting enzyme inhibitors and angiotensin II receptor antagonists $(14,15)$. This may be a novel approach to the management of AF.

Kumagai et al (16) showed that sustained AF induction in dogs with uncontrolled ventricular rates caused left ventricular dysfunction. Candesartan started one week before the onset of tachypacing, and continued throughout tachypacing, reduced AF duration. Atrial effective refractory period shortening was unaffected, indicating benefit independent of rate-dependent remodelling. In another study, Li et al (17) demonstrated that candesartan reduced interstitial fibrosis, suggesting that efficacy against AF was due to prevention of tachycardiomyopathyinduced structural remodelling. Studies suggest that the reninangiotensin-aldosterone system could affect ion channels, action potential period and impulse propagation, and facilitate re-entry. Intracellular angiotensin II reduced the L-type $\mathrm{Ca}^{2+}$ current in rat ventricular cells, whereas the opposite was observed in hamsters (18). Angiotensin II increases the L-type $\mathrm{Ca}^{2+}$ current through protein kinase C-dependent pathways (19). The T-type $\mathrm{Ca}^{2+}$ current is increased by angiotensin II stimulation (20). The rapidly activating component of 
the delayed $\mathrm{K}^{+}$rectifier current in guinea pig ventricular myocytes is increased by clinically relevant concentrations of angiotensin II $(30 \mathrm{nmol} / \mathrm{L})$, whereas the slow component of the current is decreased (10).

It is clear that MI can alter ion channel function. In rabbits at eight weeks post-MI, it appears that the abnormally prolonged action potential duration is accompanied not only by a reduction in L-type $\mathrm{Ca}^{2+}$ current activity but also an increase in $\mathrm{Na}^{+} / \mathrm{Ca}^{2+}$ exchanger current density (21). Compared with myocytes from sham-operated rats, post-MI myocytes showed significant reductions in transient outward $\mathrm{K}^{+}$current density, inward rectifier $\mathrm{K}^{+}$current density and resting membrane potential (22). However, no studies have reported the changes that occur in $\mathrm{I}_{\mathrm{K}, \mathrm{ACh}}$ in the atrium after MI. In the present study, we found that $\mathrm{I}_{\mathrm{K}, \mathrm{ACh}}$ increased after MI. However, after 12 weeks of valsartan administration, there was no change in $\mathrm{I}_{\mathrm{K}, \mathrm{ACh}}$ between the sham-operated and MI+valsartan groups. These preliminary results may show that oral valsartan can inhibit increases in $\mathrm{I}_{\mathrm{K}, \mathrm{ACh}}$ after MI. Other studies have shown that there is an imbalance between sympathetic and vagal output to the heart after MI (23). Increased sympathetic activity is associated with a high risk of malignant ventricular arrhythmias during myocardial ischemia (24). We suppose that after MI, there is an increase in sympathetic tone with parasympathetic withdrawal. The increase in $\mathrm{I}_{\mathrm{K}, \mathrm{ACh}}$ may be a response to decreased vagal tone. The mechanism for the effect of valsartan on $\mathrm{I}_{\mathrm{K}, \mathrm{ACh}}$ is not clear. Our results have qualitatively shown that increased $\mathrm{I}_{\mathrm{K}, \mathrm{ACh}}$, rather than decreased vagal input, may be the important factor responsible for AF induction after MI. Furthermore, in our study, oral valsartan inhibited increases in $\mathrm{I}_{\mathrm{K}, \mathrm{ACh}}$ after MI and significantly reduced AF induction due to VS. The present study therefore serves as a preliminary investigation of this important field, and should be followed by larger clinical trials.

\section{Limitations}

The present study has several limitations. First, due to the difference in the number of animals in which AF was induced in the three groups, we did not perform a statistical analysis of the difference in AF duration observed between the groups. Our findings therefore lacked the power to conclude on any statistical significance.

Second, we ligated the medial left anterior descending artery, a branch of the left coronary artery, to make an animal model of anterior MI. Studies have shown that AF occurring $24 \mathrm{~h}$ or more after the onset of acute MI tend to be associated more with anterior MI (25). Occlusion of the medial left anterior descending artery would be expected to cause heart failure to some extent. Sinno et al (26) demonstrated increased AF susceptibility due to slowing of local conduction in ischemic atrial remodelling. It is well known from human studies that most patients who develop AF after myocardial infarction have lost a significant amount of cardiac muscle and AF is a sequel of heart failure. However, there were no significant differences in the signs of lethargy, loss of appetite, dyspnea and peripheral edema between the MI group and sham-operated group. We failed to measure hemodynamic parameters and B-type natriuretic peptide levels.

Third, Dobrev et al (27) showed that chronic human AF induces down-regulation of $\mathrm{I}_{\mathrm{K}, \mathrm{ACh}}$ and attenuates the muscarinic receptormediated shortening of action potential duration. Earlier studies found that atrial tachycardia remodelling increases the tertiapin-Q-sensitive atrial current. In the present study, we did not investigate the changes in the tertiapin-Q-sensitive atrial current and the constitutively active $\mathrm{I}_{\mathrm{K}, \mathrm{ACh}}$ after $\mathrm{MI}$ in rabbits. It would be interesting to investigate changes in constitutively active $\mathrm{I}_{\mathrm{K}, \mathrm{ACh}}$ after MI.

Finally, other studies showed that treatment with valsartan, or the combination of captopril plus valsartan, resulted in similar changes in cardiac volume and infarct segment length after MI (28). However, in the present study, we did not investigate the effect of valsartan on MI defects in rabbits with induced AF and those without AF. Whether the effect of valsartan on MI defect is related to the induced AF requires further investigation.

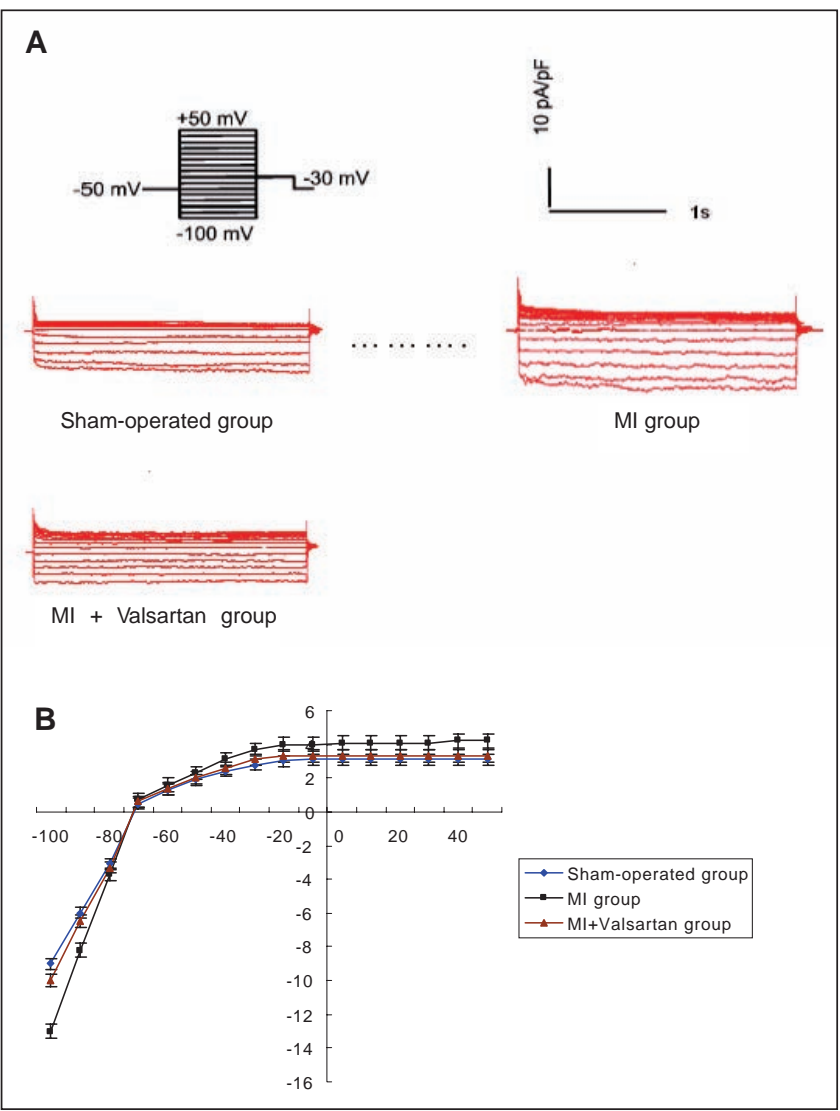

Figure 1) A Comparison of acetylcholine (ACh)-regulated $\mathrm{K}^{+}$current $\left(I_{K, A C h}\right)$ in the sham-operated group, the myocardial infarction (MI) group and the MI plus valsartan administration (MI+valsartan) group. Twosecond voltage steps were delivered to elicit $\mathrm{I}_{\mathrm{K}, \mathrm{ACh}}$ with potentials ranging from $-100 \mathrm{mV}$ to $+50 \mathrm{mV}$. The same voltage protocols were applied throughout the study. $I_{K, A C h}$ was activated in the presence of $1 \mu \mathrm{M}$ ACh. The dashed line indicates the zero current level. B The density-voltage relationship of the currents (seven cells for the sham-operated group, seven cells for the MI group and eight cells for the MI+valsartan group). The density (vertical axis) was measured in $\mathrm{pA} / \mathrm{pF}$. The voltage (horizontal axis) was measured in $m V . I_{K, A C h}$ was measured at the end of the $2 \mathrm{~s}$ pulses. The density of $I_{K, A C h}$ in the MI group was higher than in the sham-operated and $M I+$ valsartan groups

FUNDING: The present project was sponsored by the National Natural Science foundation of China No 30470704.

\section{REFERENCES}

1. Goldberg RJ, Yarzebski J, Lessard D, Wu J, Gore JM. Recent trends in the incidence rates of and death rates from atrial fibrillation complicating initial acute myocardial infarction: A communitywide perspective. Am Heart J 2002;143:519-27.

2. Wong CK, White HD, Wilcox RG, et al. New atrial fibrillation after acute myocardial infarction independently predicts death: The GUSTO-III experience. Am Heart J 2000;140:878-85.

3. Rathore SS, Berger AK, Weinfurt KP, et al. Acute myocardial infarction complicated by atrial fibrillation in the elderly: Prevalence and outcomes. Circulation 2000;101:969-74.

4. Pedersen OD, Bagger H, Kober L, Torp-Pedersen C. The occurrence and prognostic significance of atrial fibrillation/flutter following acute myocardial infarction: TRACE Study Group: Trandolapril Cardiac Evaluation. Eur Heart J 1999;20:748-54.

5. Huang CX, Zhao QY, Jiang H, Li JJ, Yang B. Experimental study of the effect of the vagus nerve on atrial electrical remodeling. J Electrocardiol 2003;36:295-300. 
6. Schauerte P, Scherlag BJ, Patterson E, et al. Focal atrial fibrillation: Experimental evidence for a pathophysiologic role of the autonomic nervous system. J Cardiovasc Electrophysiol 2001;12:592-9.

7. Chen YJ, Chen SA, Tai CT, et al. Role of atrial electrophysiology and autonomic nervous system in patients with supraventricular tachycardia and paroxysmal atrial fibrillation. J Am Coll Cardiol 1998;32:732-8.

8. Zuanetti G, Neilson J, Latini R, Santoro E, Maggioni AP, Ewing DJ. Prognostic significance of heart rate variability in post-myocardial infarction patients in the fibrinolytic era. The GISSI-2 results. Circulation 1996;94:432-6.

9. Kumagai K, Nakashima H, Urata H, Gondo N, Arakawa K, Saku K. Effects of angiotensin II type 1 receptor antagonist on electrical and structural remodeling in atrial fibrillation. J Am Coll Cardiol 2003;41:2197-204.

10. Daleau P, Turgeon J. Angiotensin II modulates the delayed rectifier potassium current of guinea pig ventricular myocytes. Pflugers Arch 1994;427:553-5.

11. Shi H, Yang B, Xu D, Wang H, Wang Z. Electrophysiological characterization of cardiac muscarinic acetylcholine receptors: Different subtypes mediate different potassium currents. Cell Physiol Biochem 2003;13:59-74.

12. Pizzetti F, Turazza FM, Franzosi MG, et al. Incidence and prognostic significance of atrial fibrillation in acute myocardial infarction: The GISSI-3 data. Heart 2001;86:527-32.

13. Finkielstein D, Schweitzer P. Role of angiotensin-converting enzyme inhibitors in the prevention of atrial fibrillation. Am J Cardiol 2004;93:734-6.

14. Wachtell K, Lehto M, Gerdts E, et al. Angiotensin II receptor blockade reduces new-onset atrial fibrillation and subsequent stroke compared to atenolol: The Losartan Intervention For End Point Reduction in Hypertension (LIFE) study. J Am Coll Cardiol 2005;45:712-9.

15. Vermes E, Tardif J-C, Bourassa MG, et al. Enalapril decreases the incidence of atrial fibrillation in patients with left ventricular dysfunction. Circulation 2003;107:2926-31.

16. Kumagai K, Nakashima H, Urata H, Gondo N, Arakawa K, Saku K. Effects of angiotensin II type 1 receptor antagonist on electrical and structural remodeling in atrial fibrillation. J Am Coll Cardiol 2003;41:2197-204.

17. Li D, Shinagawa K, Pang L, et al. Effects of angiotensin-converting enzyme inhibition on the development of the atrial fibrillation substrate in dogs with ventricular tachypacing-induced congestive heart failure. Circulation 2001;104:2608-14.

18. De Mello WC. Intracellular angiotensin II regulates the inward calcium current in cardiac myocytes. Hypertension 1998;32:976-82.

19. De Mello WC, Monterrubio J. Intracellular and extracellular angiotensin II enhance the L-type calcium current in the failing heart. Hypertension 2004;44:360-4.

20. Ferron L, Capuano V, Ruchon Y, Deroubaix E, Coulombe A, Renaud JF. Angiotensin II signaling pathways mediate expression of cardiac T-type calcium channels. Circ Res 2003;93:1241-8.

21. Litwin SE, Bridge JH. Enhanced $\mathrm{Na}(+)-\mathrm{Ca} 2+$ exchange in the infarcted heart. Implications for excitation contraction coupling. Circ Res 1997;81:1083-93.

22. Kaprielian R, Wickenden AD, Kassiri Z, Parker TG, Liu PP, Backx PH. Relationship between $\mathrm{K}+$ channel down-regulation and $[\mathrm{Ca} 2+] \mathrm{i}$ in rat ventricular myocytes following myocardial infarction. J Physiol 1999;517:229-45.

23. Schwartz P, La Rovere M, Vanoli E. Autonomic nervous system and sudden cardiac death: Experimental basis and clinical observations for post-myocardial infarction risk stratification. Circulation 1992;85(Suppl 1):177-91.

24. Schwartz P, Vanoli E, Stramba-Badiale M, De Ferrari GM, Billman GE, Foreman RD. Autonomic mechanisms and sudden death: New insights from analysis of baroreceptor reflexes in conscious dogs with and without a myocardial infarction. Circulation 1988;78:969-79.

25. Sakata K, Kurihara H, Iwamori K, et al. Clinical and prognostic significance of atrial fibrillation in acute myocardial infarction. Am J Cardiol 1997;80:1522-7.

26. Sinno H, Derakhchan K, Libersan D, Merhi Y, Leung TK, Nattel S. Atrial ischemia promotes atrial fibrillation in dogs. Circulation 2003;107:1930-6.

27. Dobrev D, Graf E, Wettwer E, et al. Molecular basis of downregulation of G-protein-coupled inward rectifying $\mathrm{K}(+)$ current IKACh in chronic human atrial fibrillation: Decrease in GIRK4 mRNA correlates with reduced IKACh and muscarinic receptor-mediated shortening of action potentials. Circulation 2001;104:2551-7.

28. Solomon SD, Skali H, Anavekar NS, et al. Changes in ventricular size and function in patients treated with valsartan, captopril, or both after myocardial infarction. Circulation 2005;111:3411-9. 